\title{
New Forms of Public Administration Activity in Poland after 1989 as an Attempt of Realization Current Social Demands
}

\begin{abstract}
The deep changes in Polish legal system and economy that took place after 1989 contributed to the emergence of new challenges for public administration. The legislator, in order to satisfy growing numbers of social demands, appointed new tasks and created a new legal form of action for public administration entities. However, not every of the new forms were fitted to classically understood administrative law. Part of this new forms at the same time combines some features characteristic for administrative law as well as typical for civil law, which gives them untypical (hybrid) character. As an example, there can be mentioned: civil law contracts with so called "overlays" (obligatory additional conditions) imposed by certain legal acts as well as administrative settlements and administrative contracts. The aim of this article is to analyze those hybrid forms of action of public administration entities in terms of implementation the objectives of regulation set by the legislator.
\end{abstract}

Keywords: new forms of public administration activity, social demands, public tasks, hybrid forms

\section{Introduction}

As a result of political changes triggered in 1989 , we could observe some legislative tendencies aimed at creating new public tasks. These tasks were created not only in reaction to the political or economic changes that had taken place before. They were primarily created in response to the growing social needs. One can have an impression that in a certain period of time the social needs determined the legislative actions regarding the regulation of the subjective scope of public tasks. In my opinion, such a phenomenon is not a novelty, as it has been observed for many years. However, the current definition of public task seems to require an update or redefinition. This is due to the fact that the constitutive feature of public tasks is their public character and statutory legal basis. We should bear in mind that the creation of new public 
tasks is influenced by several factors. First, becoming a member of the European Union, Poland obliged to adopt and adapt to certain conditions. As a result, new entities, bodies and legal institutions have been established so that specific EU guidelines could be implemented. Second, the legislator has to account for the growing needs and changing expectations of the society. It would not be surprising if it was not for the fact that their implementation is entrusted not only to public administration entities, but also to private ones. Thus, there are reasonable doubts as to the legal status of entities performing such tasks. The legislator often specifies the legal form of performing a task, which seems justified. Unfortunately, when doing so, it uses forms of private nature more willingly, for example a civil law contract. Third, both the first and the second factor contribute to the intensification of private law publicization ${ }^{1}$ and public law privatization (Helios, 2013, p. 26). These phenomena are becoming more and more frequently a subject of research and a kind of tendency noticeable in legislative actions. The main point is that there is no clearly defined boundary between public law and private law. As a consequence, the division line between possible legal forms of the implementation of tasks typical of a given branch of law is blurred.

The process of private law publicization has undoubtedly intensified due to the growing juridification of social life and the conviction that it is possible to regulate numerous aspects of our lives. It leads to a departure from the spontaneous development of the standards of conduct in interpersonal relations, which L. Fuller describes as "interactional law". This can be best observed in private law, which was actually entirely created with consideration for the freedom of individuals and the autonomy of parties' will. It seems that this trend observed in the area of private law will continue to develop, regardless of repeated demands for "deregulation" borne by supporters of economic liberalism (Srokosz, 2017, pp. 166-167).

Yet, the process of private law $^{2}$ publicization does not necessarily have to entail an automatic transition to managing certain areas of social life on the basis of the traditionally understood state authority. Some mixed forms combining elements of public law with private law are more likely to be established. In this context, the term "privatization of public law" often appears in the literature on administrative law. It is understood as the state's departure from typically authoritative methods towards the use of methods characteristic of private law. It should be noted, however, that such transformations concern mainly the areas taken over by state regulation (which used to be free from it), where the will of parties played a fundamental role. To a lesser extent, they refer to the change in the nature of traditional

${ }^{1}$ More on the issue of private law publicization: Safjan, 2007.

2 According to Safjan (2007, p. 48), the process of private law publicization can be seen primarily in four social life phenomena: authoritative interference of the state in the areas previously reserved for regulation by the parties to legal relations, gradual shift from the private law method towards the public law method in private law relations, more and more frequent promotion of social interest at the expense of individual interest, and the increasing dispersion of legal regulations regarding particular areas of social life. 
areas regulated by public law, though such transformations do occur as well. Hence, the publicization of private law will mean the adoption of various forms and degrees of state interference in private-law relations. Nevertheless, it will eventually lead to the regulation of more and more areas of social life, and thus the expansion of juridification.

One consequence of the above-mentioned legislative actions is the change of the legal forms of public tasks implementation, which is why those tasks are more and more often performed by private entities. This in turn is the opposite of private law publicization, that is public law privatization (Helios, 2013, p. 27). This phenomenon is referred to as the state's escape from the sphere of public law into the private law one and the transfer of public tasks to enterprises or corporations (Żurawik, 2010, p. 39). According to Rabska (1994, p. 14), the privatization of public tasks consists in shrinking of the public administration apparatus and removing certain tasks (or their elements) from the administrative structures ${ }^{3}$.

\section{Legal Forms of Public Administration Activity}

The legal forms of public administration activity require increased research. It is necessary to systematize particular forms and specify the features that determine their legal categories. Therefore, I would like to address a number of issues related to new legal forms described by me as hybrid.

The discussed forms of public administration activity have been the subject of the heated debate between administrative law scholars for several years. Although the concept of legal forms of activity has been defined ${ }^{4}$, it is not unanimously and widely accepted by the scholars. In addition, public administration transformations regarding the establishment of new public tasks contribute to the fact that the hitherto accepted division of the legal forms of public administration activity ${ }^{5}$ has become insufficient. It is due to the fact that

3 Examples are private schools, private hospitals.

${ }^{4}$ Legal form of action should be understood as a kind of fixed conventional or factual activity, or a set of such activities, specified by law, which is or can be separated, performed by a specified entity (or a set of entities) appointed to perform public administration tasks in order to perform public administration related tasks (Ziemski, 2005, p. 138).

5 According to Zimmermann (1956), the system of legal forms reveals the differences between legal and factual actions. Legal actions are aimed at causing specific legal effects both in the sphere of public and private law. Meanwhile, factual actions, which have a very different nature, and are sometimes referred to as material and technical activities (for instance, enforcement actions, issuing documents and certifications) may also have a legal effect, though not intended by the acting entity. The most frequently referenced is the catalogue of legal forms of administration activity defined by Starościak (1978, p. 45), i.e.: laying down universally binding regulations, issuing administrative acts, concluding contracts, concluding administrative agreements, conducting social and organization activities, performing material and technical activities. The above group of legal forms of action appears in the external relations of administration. In the case of internal relations, there will be 
there is a mutual impact (interaction) exerted by the legislator on public administration and by public administration on the legislator. Obviously, the key division of the legal forms of activity into public law (authoritative and non-authoritative) and private law is still valid. The point is that it is not exactly possible to match a given legal form to only one branch. The causes should be sought in the blurring of boundaries between legal forms of actions typical of public law and private law that occurs during the law-making process. Increasingly, the legislator establishes the civil law contract as the basic form of public task implementation (this is evident in public-private partnership, public procurement or delegating tasks to administering entities).

Hybrid legal forms of action are actually becoming the most frequently regulated forms in Polish law. Analyzing the substantive part of administrative law, one can notice that the legislator uses this form more often than the legal forms typical of administrative law, i.e. administrative decisions. Based on the science of administrative law, it should be stated that the legal forms of action that should prevail in administrative law (which is part of public law) are the ones typical of this branch of law, in particular those of imperative nature. This is mainly due to the fact that the public administration body exercising its administrative powers should settle the case, as to its substance, by way of an administrative decision. In any case, the legislator decides on the form of public task implementation by establishing a specific provision that serves as the basis for the actions undertaken by the public administration body. The body must not act as they please, i.e. in an arbitrarily chosen legal form. It is the legislator who decides about that. Needless to say, such a practice has its supporters and opponents. In my opinion, however, such action should be considered fully legitimate. The independence of the administration body as to the choice of the legal form of task implementation could pose a threat of abuse of administrative powers. Moreover, one action could take diverse forms in different parts of Poland.

Although I am not an advocate of imposing and limiting the ways of performing tasks, the legislative activity is in this case fully justified. There is one more important thing one should bear in mind. The freedom of action is an immanent feature of private law. Of course, there is a legal framework for this freedom and its basic conditions. Yet, in accordance with the principle of freedom of contract, it is the parties who decide on the content of contract and the manner it is fulfilled. This principle is regulated by the Article 3531 of the Civil Code (Machnikowski, 2005; Sośniak, 1985; Safjan 1993) and occupies a leading position among the rules applicable in the law of obligations, recognizing at the same time the autonomy of an individual to shape their contractual obligations ${ }^{6}$.

no agreements, settlements and contracts. The establishment of generally applicable laws and the issuance of administrative acts will take the form of official order.

${ }^{6}$ According to Czachórski (2004, p. 109), the principle of freedom of contract has several meanings. Firstly, entities concluding a contract have full freedom as to whether they want to establish an obligation relationship between each other and therefore it depends on them whether a contractual 
Thus, what is the hybrid legal form of activity and why is the Polish legislator increasingly establishing it as a form of public tasks implementation? How do current social needs influence or contribute to the creation of public tasks which are carried out in forms characteristic of both public and private law? The above-mentioned questions will be answered after an analysis of selected legal acts, public tasks and the classification of legal forms of activity developed by the science of law.

\section{Civil Law Contract as a Form of Public Task Implementation}

The civil law contracts used in public administration have to fulfil certain conditions and take a specific form. Their content has to be shaped in a specific way and in a written form. They also involve certain contractual penalties. Although it is all lex specialis to the Civil Code provisions on civil law contracts, representatives of the science of civil law do not claim it to be in conflict with the civil law. They rather claim it to be its over-interpretation (Stec, 2013, p. 149). As pointed out by P. Stec (whose opinion I totally agree with), the noncivil nature of contracts that do not have a "pure" code form ${ }^{7}$ is not determined by separate legal protection measures provided for in public (administrative) law. Such a judicial mode of proceeding should be treated as an extrajudicial civil law procedure. Proceedings before provincial (voivodeship) administrative courts (WSA) should be qualified as administrative cases, and those that concern material and legal matters as civil cases ${ }^{8}$. There is a view in the theory of administrative law that if a contract is concluded with the participation of public authorities, and its content and conditions are provided for in specific provisions, it should be considered a new kind of contract. In my opinion, such an assumption is incorrect. It is due to the fact that this contract would not have a public-law nature, for under the provisions of civil law it is still a civil law contract, though modified by the so-called overlays9.

The statement that public administration is increasingly reaching for legal forms typical of private (civil) law in order to implement its public tasks is not new. One can notice a kind of split among the scholars. Some perceive that phenomenon positively while some do not. In my opinion, it is difficult to make a clear choice for one of the views. On the one hand,

obligation will be established. Secondly, there is complete freedom to choose a contractor. Thirdly, the contracting parties can shape the contract's content at their own discretion, and thus bring to life the legal relationship that suits their interests. Fourthly, the term "freedom of contract" implies the far-reaching liberation of parties from legal formalities. In contractual relations, there is a rule that a mere agreement between parties is legally effective without a special form.

7 Article 66 et seq. in conjunction with Article $353^{1}$ of the Civil Code (Journal of Laws of 2018, item 1025).

${ }^{8}$ Ibidem.

9 These are the additional conditions that the contractor should meet. They are regulated in specific provisions. 
I appreciate the possibilities offered by the legislator regarding the employment of civil law contracts in the implementation of tasks by public administration bodies and entities. On the other, this phenomenon makes me feel uncertain about such issues as: protection of public interest, violation of the freedom of contract by the legislator, and establishment of hybrid agreements whose place in the legal system is difficult to determine.

The contract dominates in some areas of public administration, such as: social assistance, municipal economy, public procurement or commissioning public tasks to nongovernmental organizations. Issues related to bilateral forms of public administration activity are still a challenge for both theoreticians and practitioners. It is, above all, due to the fact that the division into civil contracts, administrative contracts, settlements or agreements is not clear (Jaworska-Dębska, 2008, p. 15). It is not surprising therefore that it is difficult to draw a clear division line between civil law and administrative law contracts. In my opinion, the legislator is more and more often applying hybrid contracts which combine the features of both civil and administrative contracts. This in turn is the cause of the dispute not only about the legitimacy of the use of such legal institutions, but also about whether it is an example of private law publicization or perhaps public law privatization.

The mere fact of using a civil law contract should not be considered negative, for it is a bilateral agreement based on a declaration of the parties' will, i.e. consensus ${ }^{10}$. This means that the parties should determine the contractual terms themselves, without the interference of third parties. In addition, a civil contract is considered (compared to administrative decision) a more economical legal form, as it makes it possible to establish a legal relationship more quickly, without a long, formal procedure.

Nevertheless, the legislator's interference in the code definition of civil law contract is not fully justified. Furthermore, systematization of the terminology of contract in administration hinders legislative activities. It is due to the fact that the legislator often uses terms that have been defined and classified in the theory of law, but in a specific legal provision they can sometimes refer to different legal institutions. One example can be agreement defined in the literature as a peculiar, bilateral form of public administration action not being a contract (Starościak, 1978, p. 89). In the law on higher education, however, it takes form of a civil law contract. This is how the legislator creates terminological chaos.

In my opinion, the problem arises when a given legal form employed to satisfy social needs displays features typical both of public and private law. The satisfaction of social needs is in public interest; thus, it should be regulated by public, not by private law. A good example is administrative settlement.

${ }_{10}$ According to Radwański (2008, p. 319), the concept of consensus involves all possible ways for the parties to establish the same legal effects of a contract. As a result, the content of the contract may be formulated by one party and entirely accepted by the other. It can also be formulated by a third party and accepted by the remaining ones. 


\section{Hybrid Legal Forms of Activity}

Legal forms of hybrid activities are not defined in the administrative law doctrine. This is due to the fact that the term "hybrid character" is an innovative term for the author of this article. Thus, as the easiest way to describe this concept? In my opinion, one should get out of what has already been established, what the legal forms of action are. In my opinion, one should get out of what has already been established, i.e. what the legal forms of action are. The hybrid character of legal forms of action gives first and foremost individual characteristics to both public and private law. The legal form of action, which has such diverse features, allows on the one hand a kind of flexibility, but on the other hand creates a problem in its proper classification. The following examples show the complexity of the legal forms of hybrid activities. Of course, the catalog of these legal forms is open and is constantly growing into those forms that have features typical of public and private law.

\section{Administrative Settlement}

Administrative settlement is defined as a written agreement between parties to administrative proceedings approved by the authority, before which the administrative proceedings are pending, after the correctness of the agreement has been verified (Wierzbowski, Wiktorowska, 1992, p. 190; Wyporska-Frankiewicz, 2010, p. 58; Kuta and Boć, 1984, p. 155). However, in the light of the amendment to the Code of Administrative Procedure ${ }^{11}$, the settlement is to be one of the ways legal disputes are solved ${ }^{12}$.

Thus, the amendment to Article 13 of the Code has led to an extension of the subjective scope of settlement in administrative proceedings (Piątek, 2017, p. 26). Starting from June 1,2017 , public administration bodies should aim at settling amicably not only cases but also points of dispute that may arise in the course of proceedings (Przybysz, 2018). The obligation of administrative bodies to amicably settle contentious issues in all the cases the nature of which permits to do so seems rather dubious when one considers the fact that public administration has so far been accustomed to its authoritative position in relations with other parties (Piątek, 2017, p. 26). An argument for the continuous improvement of the legal forms of public administration activity is the need to simplify and accelerate administrative procedures and facilitate citizens' access to public institutions (Zimmermann, 2017, p. 3). It may therefore seem that it is in the interest of modern public administration to mitigate conflicts between public and private entities. In order to do so, the legislator gradually introduces various forms of action into the legal system, such as bilateral agreements and various kinds of mediation. Deformalization of the procedure is therefore necessary, for it can bring mutual benefits. On the one hand, a public administration body can achieve the

11 The Act of 14 June 1960 Code of Administrative Procedure (Journal of Laws of 2018, item 149).

12 Article 13 of the Code of Administrative Procedure. 
goal as quickly as possible. On the other, a private entity avoids complicated procedural regimes (Zimmermann, 2017, p. 9).

The aim of the regulations introduced by the legislator was to deformalize the administrative procedure and thus make administrative proceedings quicker and free from conflict. Jurists unanimously agree that it is necessary to find the right balance between the formalism of administrative proceedings and their simplification and acceleration (Zimmermann, 2017 , p. 9). If such balance is not reached, the intended goal might not be achieved and some undesirable effects may occur.

\section{Social Contract}

Pursuant to Article 108 of the Act on social assistance ${ }^{13}$, in order to determine how to work together in solving problems of a person or a family in a difficult life situation, a social worker employed in a social welfare center or a poviat family support center may conclude a social contract with that person or family to enhance their life and professional activity and independence, or to counteract social exclusion. The content of the contract lays down the terms of cooperation between the administration entity and the party as regards resolving the latter's difficult situation. The parties to the contract establish reciprocal obligations and rights, which depend on the type of social assistance. The administration entity is obliged to provide some kind of assistance while the person who applies for this aid expresses the willingness to cooperate. At the same time, the applicant must be aware that such assistance will be provided on condition that they comply with the provisions of the contract (Wyporska-Frankiewicz, 2010, p. 268).

As regards the utility of social contract in legal transactions, it is assessed very positively, both by people working in the social assistance system and its beneficiaries.

The social contract is without a doubt a bilateral legal form of administration activity. The content of the contract is not determined by a public administration body but agreed by both parties. The contract is very similar to the civil law contract, but there are no legal grounds allowing to consider it such a legal form. Despite the fact that a considerable number of jurists are in dispute about its classification, I personally consider it an example of hybrid legal form of action in public administration. This is because it is a bilateral form of action that can be taken on terms set by the parties. Therefore, there seems to be certain kind of freedom of parties, which should translate into faster and more economical work of social workers. Unfortunately, this legal institution is not flawless. Firstly, there are no clearly defined legal consequences of breach of contract by social workers. Secondly, the term of such a contract is not specified.

\footnotetext{
13 The Act of 12 March 2004 on social assistance (Journal of Laws of 2017, item 1769).
} 


\section{Conclusions}

It can be currently observed that the legislator creates new hybrid legal forms of action in public administration. Some references to legal forms of private nature can be observed, which blurs the boundary between public law and private law. Hybrid legal forms of action are particularly visible when the legislator attempts to regulate new public tasks created in response to social needs. This is all because the administration itself, as well as public law, are to act for society and in the interests of common good. However, the problem arises when these tasks are to be carried out, for, as it was indicated above, the legal form such tasks should take is not obvious. This complexity triggers many doubts, for example as to the classification of a given form of action or as to the judicial protection of the individual's rights.

Social needs influence (contribute) to the creation of new public tasks, and thus to the creation of new legal forms of action. Such forms, thanks to which it will be possible to implement newly regulated public tasks. Society expects to meet its growing needs. And this is the example of an administrative arrangement. This is due to the fact that society is becoming more aware of its rights as well as its obligations. Therefore, in its efforts, it aims to achieve its goals, satisfy its needs in an amicable way - if it is possible. As part of the amendment - to meet these social needs - the legislator introduced in 2017 the Code of Administrative Procedure, such a legal institution - as indicated in this article.

Hybrid legal forms of action become a legal institution often created by the legislator. This is evident in substantive administrative law, in particular: in the implementation of economic tasks by government agencies (Military Property Agency, Agency for Restructuring and Modernization of Agriculture, Polish Agency for Enterprise Development, National Center for Agricultural Support, Agency for Material Reserves); in the establishment of a concession contract for construction works or services; a territorial contract pursuant to the article 5 (4c) of the Act on the principles of conducting development policy; contracts concluded in the sphere of social assistance under the Social Assistance Act of 12 March 2004.

To stand up for or against such forms of action is not possible. This is because it is need to study this issue considering various factors and, first of all, the social and the economic factor. Therefore, if the adoption of such a form would constitute the realization of social needs and at the same time would not violate the provisions of a given branch of law, it seems to me fully legitimate to establish such a form of action.

\section{References}

Boć, J., Kuta, T. (1984). Prawo administracyjne. Zagadnienia podstawowe. Warsaw: PWN. Czachórski, W. (2004). “Zobowiązania. Zarys wykładu”. In: Brzozowski A., Safjan M., Skowrońska-Bocian E., Czachórski W. (eds). Warsaw: LexisNexis.

Helios, J. (2013).“Publicyzacja prawa prywatnego - Prywatyzacja prawa publicznego w kontekście rozważań nad prawem europejskim”. Acta Universitatis Wratislaviensis, No. 3502,„Przegląd Prawa i Administracji" XCII. Wrocław, pp. 12-36. 
Jaworska-Dębska, B. (2008). “Umowy we współczesnej administracji”. In: Boć J., Dziewięcka-Bokun L.(eds.), Umowy w administracji. Wrocław: Kolonia Limited.

Machnikowski, P. (2005). Swoboda umów według art. 3531 kc Konstrukcja prawna. Warsaw: C.H. Beck. Ochendowski E. (ed.), 2013). "Prawo administracyjne”. Warsaw: LexisNexis.

Piątek, W. (2017). “Kodeks postępowania administracyjnego w świetle ustawy nowelizującej z dnia 7 kwietnia 2017 r. - ogólna charakterystyka zmian”. Zeszyty Naukowe Sądownictwa Administracyjnego, No. 5, pp. 21-36.

Przybysz, P. (2018). Kodeks postępowania administracyjnego. Komentarz aktualizowany. Lex.

Rabska, T. (1994). “Możliwości zmian ustawy samorządowej”, Samorząd Terytorialny, No. 10, pp. 12-17. Radwański, Z. (2008). “Zawarcie umowy”. In Radwański Z. (ed.), vol. 2, System prawa prywatnego. Prawo cywilne - część ogólna. Warsaw: C.H. Beck.

Safjan, M. (ed.). (2007). Pojęcie i systematyka prawa prywatnego. Warsaw: LEX.

Safjan, M. (1993). “Zasada swobody umów”. Państwo i Prawo, No. 4, pp. 12-19.

Sośniak, M. (1985). “Zasada swobody umów w prawie obligacyjnym z perspektywy schyłku XX wieku”. Studia Iuridica Silesiana, vol. 10, pp. 6-16.

Starościak, J. (1978). “Prawne formy i metody działania administracji”. In: Rabska T., Łętowski J (eds.), System prawa administracyjnego. Warsaw-Wrocław-Kraków-Gdańsk: Ossolinemum.

Stec, P. (ed.). (2013). Umowy w administracji. Warsaw: Difin.

Ura, E., Ura, E. (eds). (1999). Prawo administracyjne. Warsaw: PWN.

Wierzbowski, M., Wiktorowska, A. (1992). “Prawne formy działania administracji państwowej”. In: Służewski J. (ed.)., Polskie prawo administracyjne. Warsaw: PWN.

Wyporska-Frankiewicz, J.(ed.).(2010). Publicznoprawne formy działania administracji o charakterze dwustronnym. Warsaw.

Ziemski, K.M.(ed.).(2005). Indywidualny akt administracyjny jako forma prawna działania administracji. Poznań.

Zimmermann, J. (2017). “Kilka refleksji o nowelizacji kodeksu postępowania administracyjnego”. Państwo i Prawo, No. 8, pp. 3-24.

Zimmermann, M. (1956). “Formy działania administracji państwowej. Akt administracyjny”. In: Jaroszyński, M., Zimmermann M., Brzeziński W. (eds.), Polskie prawo administracyjne. Czesść ogólna. Warsaw: PWN. Żurawik, A. (2010). "Problem publicyzacji prawa prywatnego w kontekście ustrojowym”. Państwo i Prawo, No. 5, pp. 32-41.

\section{Acts of Law}

The Act of 23 April 1964 the Civil Code (Journal of Laws of 2018, item 1025).

The Act of 14 June 1960 Code of Administrative Procedure (Journal of Laws of 2018, item 149).

The Act of 12 March 2004 on social assistance (Journal of Laws of 2017, item 1769).

\section{Author}

\section{Paulina Bieś-Srokosz}

paulinabiessrokosz@interia.pl // p.bies@ajd.czest.pl - Assistant Professor in the Institute of Law, Administration and Management at Jan Dlugosz University in Czestochowa; Jan Dlugosz University, Waszyngtona st. 4/8, 42-200 Częstochowa, Poland 